\title{
Influence of short crop rotations and fertilizer system on weed infestation of crops of sugar beet
}

\author{
O. Torlina \\ Institute of Bioenergy Crops and Sugar Beet NAAS, Kyiv,
}

The purpose. To determine influence of links of short crop rotations and fertilizer system on formation of weed infestation of crops of sugar beet. Methods. Long stationary experiment. Account of weeds in sowings of sugar beet was carried out in frames $\left(1,25 \mathrm{~m} \times 0,20 \mathrm{~m}=0,25 \mathrm{~m}^{2}\right)$ which were superimposed on diagonal of a plot in 4 places. Species composition of weeds was determined during mass shoots of plants of sugar beet by means of V.P. Stupakova manual. Results. Influence of links of short crop rotations and fertilizer system in sowings of sugar beet upon quantitative change of species composition of weeds is studied. At use in crop rotation with short rotation of a field with bare fallow purification of sowings of sugar beet is observed. Conclusions. For a zone of insufficient humidification in Foreststeppe the most efficient short crop rotation in control of weed infestation of crops of sugar beet is graintilling one: 1) bare fallow, 2) winter wheat, 3) sugar beet, 4) barley. The factor of bare fallow considerably reduced aggregate number of weeds in sowings of beet sugar.

Key words: weeds, sugar beet, fertilizer system, link of crop rotation, typical weakly alkaline black earth.

Problem statement. Increasing weed infestation of crops is the main reason for declining sugar beet root yield. In the struggle for moisture, nutrients and solar energy, weeds are more competitive than sugar beet (Tkachenko \& Roik,1998; Tsvei, 2014). Effect of weeds on sugar beet is especially significant in the first period of vegetation (from emergence to closing rows) (Horobets et al., 2000; Fedorenko \& Tsvei, 2012). Insufficient weed control may lead to a decline in sugar beet productivity of $40 \mathrm{t} / \mathrm{ha}$, that is about $80 \%$. To illustrate, during 80 days of joint vegetation, weed complex absorbs from the soil such amount of nutrients, which is sufficient for the production of 45-55 t/ha sugar beet root (Ivashchenko et al., 2002). Therefore, the quality of cleaning the field from weeds is one of the most important factors affecting yield, often more powerful than fertilizers, planting density, soil tillage etc. [Navalnev et al., 2006; Tsvei, 2014).

The key to success in combating weeds in sugar beet crops is a rational system of agronomical and chemical methods (Dvoryankin \& Ascheulov, 2005; Barshtain et al., 1997; Makukh et al., 2015; Navalnev et al., 2006; Tkachenko \& Roik,1998; Fedorenko \& Tsvei, 2012; Tsvei, 2014).

In sugar beet crops, weed density significantly increased under the effect of fertilizers (Ivanets \& Derkach, 2000). Thus, in short crop rotation, the number of weeds against the fertilized background was greater than against unfertilized background. This phenomenon can be explained by the fact that weeds use nutrients much more intensively than crops (Makukh et al., 2015; Gorobets et al., 2000).

The purpose of the research was to investigate the effect of short crop rotation link and fertilization practice on the weed infestation of sugar beet crops.

Research methods. The study on the effect of fertilization practice and short crop rotation link on weed infestation of sugar beet was carried out at the Veselopodilska Research Breeding Station (Semeniv district, Poltava region) in a long-term stationary experiment. The soil type for the experiment was typical deep weakly sodic chernozem with $\mathrm{pH}_{\text {sal }}$ of 7.5 , soil carbon (by Tyurin method) 4.5 to $4.8 \%$; $\mathrm{NO}_{3}$ and $\mathrm{NH}_{4}$ (by the CINAO method); $\mathrm{P}_{2} \mathrm{O}_{5}$ and $\mathrm{K}_{2} \mathrm{O}$ (by Machigin method) of 30 and $100 \mathrm{mg} / \mathrm{kg}$, respectively. Short crop rotations for the experiment were as following: grain - row crop rotation (with the shares of row crops and grain crops of 50 and $50 \%$, respectively: 1) maize for silage, 2) winter wheat, 3) sugar beet, 4) barley; grain - row crop rotation (with the shares of row crops and grain crops of 25 and 75 $\%$, respectively: 1) pea, 2) winter wheat, 3) winter wheat, 4) sugar beet; grain - bare fallow - row crop 
rotation (with the share of grain crops of $50 \%$, sugar beet $25 \%$ and bare fallow $25 \%$ : 1) bare fallow, 2) winter wheat, 3) sugar beet, 4) barley.

Fertilization for the experiment was as following: treatments $27,45,63$ - no fertilizers; treatments 28 , 47, 63 - 25 t/ha manure $+\mathrm{N}_{90} \mathrm{P}_{120} \mathrm{~K}_{90}$; treatments $29,48-25$ t/ha manure + straw $+\mathrm{N}_{90} \mathrm{P}_{120} \mathrm{~K}_{90}$. Fertilizers were introduced in the form of ammonium nitrate, granular superphosphate, potassium chloride and semirotten manure. The sugar beet hybrid for the experiment was Bulava and it was grown in accordance with convenient agronomical practices for a zone of insufficient moisture.

Weed accounting in sugar beet sowings was carried out using a frame measured $1.25 \times 0.20 \mathrm{~m}=0.25$ $\mathrm{m}^{2}$, which was placed in four places diagonally; Weed species composition in sugar beet was determined during the period of active emergence of sugar beet plants using the reference book (Stupakov 1984).

Research results. Weed infestation of crops is one of the factors reducing the efficiency of all measures (fertilizers, varieties, etc.), aimed at increasing yield (Tsvei, 2014).

Our research showed that in short crop rotation, weed infestation of sugar beet was affected by both fertilization practice and crop rotation link. Particularly, in the treatments without fertilization, the highest level of weed infestation per $1 \mathrm{~m}^{2}$ was observed in sugar beet sown in grain - row crop rotation in the link after winter wheat (286.6), and in the link of silage maize (183.2), which was higher than in the link of bare fallow by 221.2 and 117.8 , respectively. This difference was due to the effect of preceding crop. In weed species composition, dominating were monocotyledons with the number per square meter of 135.9 , 248.4 and 38.6 , which made up $74.1,86.5$, and $59.0 \%$, respectively, of the total number of weeds.

When introducing $25 \mathrm{t} /$ ha manure $+\mathrm{N}_{90} \mathrm{P}_{120} \mathrm{~K}_{90}$ in sugar beet, the number of weeds was as follows: in the link of silage maize 217.7, in two fields of winter wheat 323.0, and in bare fallow 38.2. Consequently, the cultivation of beet sugar in the link with bare fallow contributes to a significant reduction in weed infestation. In weed species composition, dominating in the link of silage maize and bare fallow were dicotyledonous, and only in two links of winter wheat monocotyledons prevailed. This was due to the fact that the two fields of winter wheat were not competitive, which promoted more intensive weed infestation.

Combination of 25 t/ha manure + straw $+\mathrm{N}_{90} \mathrm{P}_{120} \mathrm{~K}_{90}$ promoted an increase in weed infestation. Specifically, the number of weeds in the link of silage maize was 217.7, in two fields of winter wheat 323.0, whereas in bare fallow 14.3. In this system of fertilization, in the weed species composition, monocotyledons dominated.

The most complex situation in terms of weed infestation of sugar beet was observed in grain - row crop rotation, with sugar beet sown in two fields after winter wheat. For the application of $25 \mathrm{t} /$ ha manure $+\mathrm{N}_{90} \mathrm{P}_{120} \mathrm{~K}_{90}$, the number of weeds was 323.0, of which dicots 61.3 and monocots 261.7.

In order to successfully implement the weed control system for certain crop, it is important to have sufficient information on the weed species composition (Fedorenko \& Tsvei, 2012). In weed species composition in the beginning of the vegetation of sugar beet, ephemera, wintering, early spring, late spring, root-sucker and branch-root weeds marked.

Fertilizers contributes most to the development of various types of annual cereal weeds (genus Gramineae), green amaranth (Amaranthus retroflexus L.) which has an extremely high seed yield, white clover (Chenopodium album L.), and green foxtail (Setaria glauca L.).

When 25 tha manure $+\mathrm{N}_{90} \mathrm{P}_{120} \mathrm{~K}_{90}$ was applied, the number of cereal weeds (per $1 \mathrm{~m}^{2}$ ) was as following: in the link of silage maize 96.9 , in two fields of winter wheat 254.7, in bare fallow 14.3, and in the treatments without fertilizers $127.9,243.1$ and 37.3 , respectively. This system of fertilizer contributed to the reduction of cereal weeds in the first two systems, and the third supported their number on the same level.

When 25 t/ha manure + straw $+N_{90} P_{120} K_{90}$ was introduced the number of weeds (per $1 \mathrm{~m}^{2}$ ) was as following: in the link with silage maize 168.4 (by 40.5 higher than in the treatment without fertilizers); in the link of bare fallow 31.5 (by 5.8 lower than in the treatment without fertilizers). This confirms that bare fallow reduces the number of cereal weeds in the crop rotation. 
During the emergence, when introducing $25 \mathrm{t} /$ ha manure $+\mathrm{N}_{90} \mathrm{P}_{120} \mathrm{~K}_{90}$, the number of chickweed plants (Stellaria media L.) in the link of silage maize amounted to 2.7, in two fields of winter wheat 5.3, in bare fallow 0.9 , and in the treatments without fertilizers 5.3, 7.1 and 5.7, respectively. When introducing $25 \mathrm{t} / \mathrm{ha}$ of manure + straw $+\mathrm{N}_{90} \mathrm{P}_{120} \mathrm{~K}_{90}$ in the link of maize silage, the number of weeds (per $1 \mathrm{~m}^{2}$ ) was 1.7, which was 2.7 less than the treatment without fertilizers, and in bare fallow 5.3 that was at the same level.

The number of lamb's quarter (Chenopodium album L.) (per $1 \mathrm{~m}^{2}$ ) with application of $25 \mathrm{t} /$ ha manure + $\mathrm{N}_{90} \mathrm{P}_{120} \mathrm{~K}_{90}$ was the following: in the link of silage maize 4.0; bare fallow 4.5, in two fields of winter wheat 2.7, which was by $0.4,0.3$ and 1.7 less compared to the treatment without fertilizers. Application of 25 t/ha manure + straw $+\mathrm{N}_{90} \mathrm{P}_{120} \mathrm{~K}_{90}$ resulted in the following number of weeds (per $1 \mathrm{~m}^{2}$ ): in the link of silage maize 1.7, in bare fallow 5.3.

Among the late spring weeds whose seeds germinate in the event of stable soil warming, the dominant was green amaranths (Amaranthus retroflexus L.). In terms of the introduction of the organic and mineral fertilizers, its number (per $1 \mathrm{~m}^{2}$ ) in the link of silage maize was 82.1 , bare fallow 13.7, in two fields of winter wheat 28.4, which was greater than in the treatment without fertilizers by $65.3,6.1$, and 11.1, respectively. The largest infestation was noted in grain - row crop rotation in the link of silage maize; specifically, 82.1 when introducing 25 t/ha manure $+\mathrm{N}_{90} \mathrm{P}_{120} \mathrm{~K}_{90}$ and 41.7 when applying $25 \mathrm{t} /$ ha manure + straw $+\mathrm{N}_{90} \mathrm{P}_{120} \mathrm{~K}_{90}$.

Application of $25 \mathrm{t} /$ ha manure + straw $+\mathrm{N}_{90} \mathrm{P}_{120} \mathrm{~K}_{90}$ resulted in the following number of green amaranths plants $\left(\right.$ per $1 \mathrm{~m}^{2}$ ): in the link of silage maize 41.7, bare fallow 8.7, and in the treatments without fertilizers 16.8 and 7.6 , respectively.

Among the wintering weeds, foxtail gray (Setaria glauca L.) dominated with the following number: at the introduction of $25 \mathrm{t} /$ ha manure $+\mathrm{N}_{90} \mathrm{P}_{120} \mathrm{~K}_{90}$ in the link of silage maize 3.6, in two fields of winter wheat 7.0. In the grain - row crop rotation in the link of bare fallow, foxtail gray was observed only in the treatment without fertilizers $\left(1.3\right.$ per $\left.\mathrm{m}^{2}\right)$. This testifies the fact that grain - row crop rotation with sugar beet sown in the link of bare fallow was more effective against the foxtail gray.

In the research, perennial sowthistle (Sonchus arvensis L.). prevailed among the perennial root suckers and branch roots weeds. In grain - row crop rotation in the link of silage maize, their number when introducing 25 t/ha manure $+\mathrm{N}_{90} \mathrm{P}_{120} \mathrm{~K}_{90}$ and 25 t/ha manure + straw $+\mathrm{N}_{90} \mathrm{P}_{120} \mathrm{~K}_{90}$ was 0.4 and 2.3, respectively, while in the treatment without fertilizers 0.4 .

It should be noted that other types of dicotyledonous weeds in sugar beet sowings were scarce and their number in different systems of fertilization was similar.

Table 1. Species and quantitative composition (per $1 \mathrm{~m}^{2}$ ) of weeds in sugar beet sowings in the links of short-crop rotation, average from 2012 to 2014 (Veselopodilska Research Breeding Station)

\begin{tabular}{|c|c|c|c|c|c|c|c|c|}
\hline \multirow{3}{*}{ Weed species } & \multicolumn{8}{|c|}{ Content } \\
\hline & \multicolumn{3}{|c|}{$\begin{array}{l}\text { Grain - row crop rotation } \\
\text { (the link of maize for } \\
\text { silage) }\end{array}$} & \multicolumn{3}{|c|}{$\begin{array}{l}\text { Grain - row crop } \\
\text { rotation (the link of } \\
\text { bare fallow) }\end{array}$} & \multicolumn{2}{|c|}{$\begin{array}{l}\text { Grain - row crop } \\
\text { rotation (in the link } \\
\text { of winter wheat } \\
\text { fields) }\end{array}$} \\
\hline & 27 & 28 & 29 & 45 & 47 & 48 & 63 & 65 \\
\hline \multicolumn{9}{|l|}{ Ephemerous } \\
\hline $\begin{array}{l}\text { Chickweed } \\
\text { (Stellaria media L.) }\end{array}$ & 5.3 & 2.7 & 0.4 & 5.7 & 0.9 & 0.9 & 7.1 & 5.3 \\
\hline \multicolumn{9}{|l|}{ Early spring } \\
\hline $\begin{array}{l}\text { Lamb's quarter (Chenopodium } \\
\text { album L.) }\end{array}$ & 4.4 & 4.0 & 1.7 & 4,8 & 4.5 & 5.3 & 4.4 & 2.7 \\
\hline $\begin{array}{l}\text { Wild buckwheat } \\
\text { (Polygonum convolvulus L.) }\end{array}$ & 1.3 & 4.4 & 4.9 & - & - & - & - & - \\
\hline
\end{tabular}




\begin{tabular}{|c|c|c|c|c|c|c|c|c|}
\hline $\begin{array}{l}\text { Silene notturna } \\
\text { (Melandrium noctiflorum L.) }\end{array}$ & 2.7 & 2.3 & 0.9 & - & - & - & 2.1 & 8.8 \\
\hline \multicolumn{9}{|l|}{ Late spring } \\
\hline $\begin{array}{l}\text { Common hemp-nettle } \\
\text { (Galeopsis tetrahit L.) }\end{array}$ & 8.0 & 6.8 & 4.4 & 2.7 & 1.2 & 5.3 & 1.7 & 0.8 \\
\hline $\begin{array}{l}\text { Black nightshade } \\
\text { (Solanum nigrum L.) }\end{array}$ & 8.4 & 9.7 & 11.1 & 3.1 & 2.7 & 0.9 & 4.8 & 12.4 \\
\hline $\begin{array}{l}\text { Green amaranth } \\
\text { (Amaranthus retroflexus L.) }\end{array}$ & 16.8 & 82.1 & 41.7 & 7.6 & 13.7 & 8.4 & 17.3 & 28.4 \\
\hline \multicolumn{9}{|l|}{ Wintering } \\
\hline $\begin{array}{l}\text { Field pennycress } \\
\text { (Thlaspi arvense L.) }\end{array}$ & - & - & 0.4 & - & - & - & - & 0.4 \\
\hline $\begin{array}{l}\text { Green foxtail } \\
\text { (Setaria glauca L.) }\end{array}$ & 8.0 & 3.6 & 6.3 & 1.3 & - & - & 5.3 & 7.0 \\
\hline \multicolumn{9}{|c|}{ Perennial (root suckers and branch roots) } \\
\hline $\begin{array}{l}\text { Perennial sowthistle (Sonchus } \\
\text { arvensis L.) }\end{array}$ & 0.4 & 0.4 & 2.3 & - & - & - & - & - \\
\hline $\begin{array}{l}\text { Creeping thistle } \\
\text { (Cirsium arvense L.) }\end{array}$ & - & 0.4 & - & 0.9 & - & - & 0.4 & - \\
\hline Cereals (Monocot) & 127.9 & 96.9 & 168.4 & 37.3 & 14.3 & 31.5 & 243.1 & 254.7 \\
\hline Monocotyledon & 135.9 & 100.5 & 174.7 & 38.6 & 14.3 & 31.5 & 248.4 & 261.7 \\
\hline Dicotyledon & 47.3 & 117.2 & 67.8 & 26.8 & 23.9 & 22.1 & 38.2 & 61.3 \\
\hline Total & 183.2 & 217.7 & 242.5 & 65.4 & 38.2 & 53.6 & 286.6 & 323.0 \\
\hline
\end{tabular}

\section{Conclusions}

In short crop rotation, weed infestation of sugar beet was affected more by crop rotation link than fertilization practice.

When having introduced $25 \mathrm{t} /$ ha manure $+\mathrm{N}_{90} \mathrm{P}_{120} \mathrm{~K}_{90}$, the total number of weeds per $1 \mathrm{~m}^{2}$ was as following: in the link of silage maize 217.7 and bare fallow 38.2. The most significant weed infestation (323) was observed in the link of sugar beet sown in two fields after winter wheat.

The largest number of monocot weeds (per $1 \mathrm{~m}^{2}$ ) marked against the background of $25 \mathrm{t} /$ ha manure + $\mathrm{N}_{90} \mathrm{P}_{120} \mathrm{~K}_{90}$ : in the link of silage maize 100.5, bare fallow14.3, in two fields of winter wheat 261.7.

In weed species composition, green amaranth prevailed. When introducing 25 t/ha manure + $\mathrm{N}_{90} \mathrm{P}_{120} \mathrm{~K}_{90}$, in the link of silage maize, the number of weeds was 82.1 , bare fallow 13.7 , and in two fields of winter wheat 28.4. Introduction of $25 \mathrm{t} /$ ha manure + straw $+\mathrm{N}_{90} \mathrm{P}_{120} \mathrm{~K}_{90}$ in the link of silage maize resulted in 41.7 , and bare fallow 8.7 weeds per $1 \mathrm{~m}^{2}$.

\section{Bibliography}

1. Ivashchenko, O. O., Sokol-Popovskyi, A. M., \& Kunak, V. D. (2002). Weeds in agrophytocenoses. Tsukrovi buriaky [Sugar beet], 5, 10. [in Ukrainian]

2. Dvoryankin, E. A. \& Ascheulov, A.E. (2005). Herbicides combined with growth promoters on sugar beet. Saharnaya svekla [Sugar beet], 5, $10-11$. [in Russian]

3. Stupakov, V. P. (1984). Dovidnyk po burianakh [Weed Directory Guide]. Kyiv: Urozhai. [in Ukrainian] 
4. Barshtain, L. A., Shkarednyi, I. S., Yakymenko V. M., \& Hlushchenko, I. V. (1997). Instytut tsukrovykh buriakiv UAAN (zbirnyk naukovykh prats),vypusk yuvileinyi [Institute of Sugar Beet UAAS (Research papers), anniversary issue] (pp. 141-158). Kyiv: Ahrarna nauka. [in Ukrainian]

5. Ivanets, G. I. \& Derkach, H. Yo. (2000). Minimalization of pre-sowing and post-sowing tillage in sugar beet. Zbirnyk naukovykh prats Instytutu Tsukrovykh buriakiv [Scientific papers of Institute of Sugar beet], 2(2), 73-76. [in Ukrainian]

6. Makukh, Ya. P., Remeniuk, S. O. \& Moshkivska, S. V. (2015). Heracleum sosnowskyi in barley. Karantyn i zakhyst roslyn [Quarantine and plant protection], 10, 6-8. [in Ukrainian]

7. Navalnev, V. V., Domanov, N. M. \& Shapovalov, N. K. (2006). Agrotechnology, which enshures root yield of 40-45 $t$ and sugar yield of 5.5-6.0 t per hectare. Saharnaya svekla [Sugar beet], 7, 32-34. [in Russian]

8. Horobets, A. M., Zoria, S. Yu. \& Shkarednyi, I. S. (2000). Peculiarities of the effect of crop rotation, tillage and fertilizers on weed infestation in sugar beet in the subzone of inadequate moistening. Zbirnyk naukovykh prats Instytutu Tsukrovykh buriakiv [Scientific papers of Institute of Sugar beet], 2(2), 45-50. [in Ukrainian]

9. Tkachenko, O. M. \& Roik, M. V. (1998). Ukrainska intensyvna tekhnolohiia vyrobnytstva tsukrovykh buriakiv [Ukrainian intensive production technology for sugar beet]. Kyiv: Akadempres. [in Ukrainian]

10. Fedorenko , V. P. (Ed.) \& Tsvei, Ya. P. (2012). Ahrotekhnichnyi metod zakhystu Roslyn. In Sratehiia i taktyka zakhystu roslyn Agrotechnical method of plant protection [Sgrategiya and tactics of plant protection]. Vol. 1(7). Kyiv: Alpha-Stevia. [in Ukrainian]

11. Tsvei, Ya. P. (2014). Fitosanitarnyi stan sivozmin. In Rodiuchist gruntiv i produktyvnist sivozmin [Soil fertility and crop rotation productivity]. Kyiv: COMPRINT. [in Ukrainian]

12. Bartels, M. (2010). Erfolgreiche Unkraut - bekämpfung in Zuckerrüben. Zuckerrubbe,1,14-16. 